\title{
Studies on Physical and Hunter Colour of Gamma Irradiated Tofu (Soy Paneer)
}

\author{
S.B. Maurya ${ }^{1^{*}}$, S.S. Shukla ${ }^{1}$ and Lokesh Gour ${ }^{2}$ \\ ${ }^{1}$ Department of food science and Technology, ${ }^{2}$ Department of Plant Breeding and Genetics \\ Jawaharlal Nehru Krishi Vishwa Vidyalaya, Jabalpur (MP), India \\ *Corresponding author
}

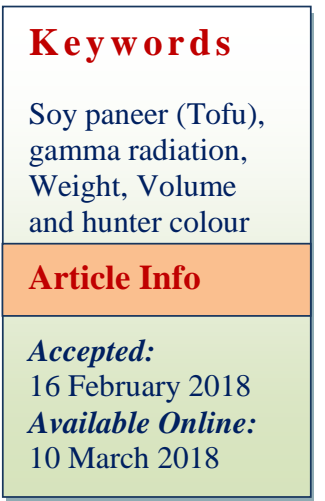

\section{A B S T R A C T}

The Soybean (Glycine max L.) variety JS-97 52 used for preparation of soy milk \& tofu (Soy paneer). Tofu and soy milk producers prefer the higher protein cultivars. The shelf life of tofu is very less therefore to extend it, effect of different doses of gamma radiation on physical \& hunter colour of tofu using packaging material as BOPP, HDPE and LDPE at $0,5,10,15,20$ days have been studied. The Hunter colour $\mathrm{L}$, a and $\mathrm{b}$ value of tofu shows that the colour of tofu varies from light creamy with fine yellow colour. As earlier researchers stated that colour of product changed after irradiation. In this finding seems to be that effect of radiation may be due to removal of water. The biomolecules may also undergo for conformational changes due to radiation which may cause the variation in the concentration during storage. LDPE shows non-significant contribution of treatment during storage period for moisture (0-20 days), volume (0-20days) and weight (0-20day), respectively, however for remaining period the effect on the content of above constituents was significant. In a nutshell it is deduced from the findings of present investigation and their justification that $1.25 \mathrm{kGy}$ gamma radiation treatments in combination with LDPE can be successfully utilized for extension of shelf life up to 15 days without sacrificing the quality of product. The standardized value of gamma radiation treatment and packaging can be successfully translated at commercial and domestic scale.

\section{Introduction}

Soybean is considered to be a source of complete protein. It contains significant amounts of all the essential amino acids that must be provided to the human body because of the body's inability to synthesize them. Consumption of soy may also reduce the risk of colon cancer, possibly due to the presence of sphingolipids (Maurya et al., 2018). Approximately $85 \%$ of the world's soybean crop is processed into soybean meal and vegetable oil (Dahlquist, 2013). Tofu and soy milk producers prefer the higher protein cultivars. Tofu is made by coagulating hot soymilk in tofu machine. Tofu has bland flavour it absorbs the flavour of the food with which it is cooked. It is sold in loose, vacuum packed and water filled pouches and is increasingly available in shops. Regular use reduces the cholesterol level. Helps avoid osteoporosis (bone weakness) some of the 
nutrients found in soy protein are anticancer agents. It is a complete vegetable protein containing all nine essential amino acids.

The shelf life of tofu is very poor (5-7 days) at ambient temperature. The prepared fresh tofu is placed in cold water for preservation and storage. It is sold in loose, vacuum packed and water filled pouches and is increasingly available in shops. Colour attribute of a product is of prime importance to the consumer as a product quality criterion, since consumers associate it with freshness and is critical in the acceptance of a particular product among others (Campbell et al., 2004). Use of chemical preservation is also hazardous to health damaging kidney and other parts of organ. Food processing by employing radiation is well established as a physical, non-thermal mode of food preservation (cold-pasteurization) that processes foods at or nearly at ambient temperature. Irradiation of food products causes minimal modification in the flavour, colour, nutrients, taste, and other quality attributes of food (Kortei et al., 2015). Codex Alimentarius Commission has endorsed a green irradiation logo for marketing of those foods in which specific benefits are achieved by applying appropriate doses, and those duly permitted under the Prevention of Food Adulteration Act (PFA) Rules, 1954, can be processed by radiation (FAO/WHO, 1976). However, the levels of modification (in flavour, colour nutrients, taste etc.) might vary depending on the basic raw material used, irradiation dose delivered and on the type of radiation source employed (gamma, X-ray, UV, electron beam) (Maxis et al., 2009).

As the information on application of low dose of gamma radiation along with packaging requirements for enhancing the shelf life of tofu and the effect of gamma irradiation on physical properties and consumer acceptability of radiated food (tofu) are quite meager, therefore the studies on physical \& hunter colour of gamma irradiated tofu (soy paneer) were carried out here.

\section{Materials and Methods}

\section{Exploration and collection of experimental materials}

The various experimental techniques, materials and methodologies used for the study of effect of different doses of gamma radiation on physical $\&$ hunter colour of tofu (Soy paneer). The present investigation was carried out in the Department of Food Science and Technology, College of Agriculture, Jabalpur (M.P.). The Soybean (Glycine max L.) variety JS-9752 was collected from department of plant breeding and\& genetics, College of Agriculture, Jabalpur for preparing tofu. Different type packaging materials i.e. BOPP, LDPE and HDPE were purchased from the Priya Darshani Cooperative Store, Adhartal, Jabalpur.

\section{Experimental plan and design}

In accordance with the objectives of investigation, to study the effect of gamma radiation on physical $\&$ hunter colour of tofu attributes during storage period of twenty days in various packaging materials i.e. BOPP, LDPE and HDPE. The experiment was conducted in complete randomized design with three replications. The variables (Gamma radiation doses) were selected taking into consideration the maximum and minimum values used in previous experiments (Kortei et al., 2015). The experimental plan was consisted of five variables doses of gamma radiation (Control, $0.25 \mathrm{kGy}, 0.50 \mathrm{kGy}, 0.75 \mathrm{kGy}, 1.0 \mathrm{kGy}$ and $1.25 \mathrm{kGy})$, three different packaging material (BOPP, LDPE, HDPE) and storage period up to 20 days $(0,5,10,15$, and 20 days). The experimental plan is presented in table 1 . 


\section{Evaluation of physical properties of tofu}

\section{Weight and volume of tofu}

The weight of tofu was determined using electronic scale. The averages of three determinations were reported in gram $(\mathrm{g})$.

The volume of tofu was determined by water displacement method. The results were expressed as $\mathrm{ml}$ of rapeseed displaced.

\section{Moisture}

The moisture content in the sample was estimated according to the method of AOAC, (1984). The sample $(5 \mathrm{~g})$ was taken in preweighed moisture box, dried at $105^{\circ} \mathrm{C}$ for $24 \mathrm{~h}$ in hot air oven, cooled in desiccators again weighed. The difference in weight of moisture box represents the moisture content of the sample.

$$
\text { Moisture }(\%)=\frac{\begin{array}{c}
\text { Difference in the } \\
\text { weight }
\end{array}}{\begin{array}{c}
\text { Weight of the } \\
\text { sample }
\end{array}} \times 100
$$

Principle of operation and measurement of colour

The colour measurement is based on the principle of reflection of light. The light is reflected to the sensor and the sensor in turn reads the product characteristics and determines the value of $\mathrm{L}, \mathrm{a}$ and $\mathrm{b}$ and gives the colour of the product. Hunter Lab performs integration of reflectance/ transmittance values over the visible spectrum to arrive at tristimulus $\mathrm{X}, \mathrm{Y}$ and $\mathrm{Z}$ values. These values stimulate the colour matching response functions of human observer as defined by the 1964 CIE $10^{\circ}$ standard observer (Anon, 1998). The relationship between CIE XYZ values and the $\mathrm{x}, \mathrm{y}$ chromacity coordinates are as follows:

$$
x=\frac{X}{X+Y+Z} \quad y=\frac{Y}{X+Y+Z} \text { eq... 3.1 }
$$

The opponent - colour scale gives measurement of colour in units of approximate visual uniformity throughout the colour solid. Thus in the Hunter scale ' $L$ ' measures lightness and varies from 100 for perfect white to 0 for black, approximately as the eye would evaluate it.

The chromaticity dimensions ( $a$ and $b$ ) give understandable designations of colour as follows:

' $a$ ' measures redness when positive, gray when 0 and green when negative.

'b' measures yellowness when positive, gray when 0 and blue when negative.

The relationship between the CIE Lab scale and the CIE XYZ scale for any illuminant referenced in ASTM E 308 is as follows:

$$
\begin{aligned}
& \mathrm{L}=116_{3} \sqrt{ } \mathrm{Y} / \mathrm{Y}_{\mathrm{n}}-16 \\
& \mathrm{a}=500\left({ }_{3} \sqrt{\mathrm{X}} / \mathrm{X}_{\mathrm{n}}-{ }_{3} \sqrt{ } \mathrm{Y} / \mathrm{Y}_{\mathrm{n}}\right) \\
& \mathrm{b}=200\left({ }_{3} \sqrt{ } / \mathrm{Y}_{\mathrm{n}}-{ }_{3} \sqrt{ } \mathrm{Z} / \mathrm{Z}_{\mathrm{n}}\right)
\end{aligned}
$$

Where $\mathrm{X}, \mathrm{Y}, \mathrm{Z}$ are CIE tristimulus values : $\mathrm{Xn}$, $\mathrm{Yn}$ and $\mathrm{Zn}$ are tristimulus values of the standard illuminant.

\section{Procedure}

The sensor of Hunter Lab was standardized with a white and black tile provided with the machine.

The samples were taken for measurement of colour using Hunter Lab model colour flex colorimeter colour in terms of L,a,b scale. Sample colour was measured by placing the tofu over $10 \mathrm{~mm}$ aperture of sample measurement port of the colorimeter and the reading was observed. 


\section{Results and Discussion}

\section{Physical properties of tofu}

\section{Weight and volume}

The table 2 and table 3 comprises the results of effect of different doses of gamma radiation on weight and volume of tofu packed in various packaging materials and stored for varying storage period.

The weight of tofu packed in BOPP, LDPE and HDPE varied from 50- 50.77, 50-50.65 and $50-50.85 \mathrm{~g}$ respectively (Table 2 ). The analysis of variance table indicates that the Fratio of the model was lower as compared with the table value of at $5 \%$ level of significance. There was no significant difference among the different treatment have been observed for weight of tofu. The volume of tofu packed in BOPP, LDPE and HDPE varied from 50- 50.9, 50-50.6 and 50-50.7 ml respectively (Table 3 ). The F-ratio of the model was lower as compared with the table value of at $5 \%$ level of significance. There was also no significant difference among the treatment combination for volume of tofu. The findings indicate that gamma radiation doses could not contribute any significant effect on increase or decrease in volume of tofu during storage.

\section{Moisture}

The table 4 reveals the results of moisture content of tofu packed in BOPP, varied from 73.6-74.6, 74.7-73.58, 74.64-73.66, 74.7873.78 and $76.87-75.96$ per cent at $0,5,10,15$ and 20 days of storage period respectively. The analysis of variance table indicates that the F-ratio of the model was higher as compared with the table value of at $5 \%$ level of significance. The significant difference among the different treatment combination has been observed during the storage of tofu up to 15 days however a non significant difference has been seen at 20 days of storage.

The moisture content of tofu packed in LDPE shows that it varied from 73.52-74.5, 73.5$74.61,73.6-74.6,73.68-74.67$ and 74.2876.24 per cent at $0,5,10,15$ and 20 days of storage period (Table 4) respectively. During the storage period the moisture content varied from 73.52-76.24. The F-ratio of the model was significant which indicates significant difference among the different treatment combination on moisture content of tofu packed in LDPE for $0,5,10$ and 15 days however a non significant difference has been seen at 20 days of storage.

The result presented in Table 4.3 indicates that moisture content of tofu packed in HDPE varied from 73.57-74.57, 73.64-74.62, 74.25$75.01,73.72-74.81,75.56-77.51 \mathrm{per}$ cent at $0,5,10,15$ and 20 days of storage period respectively. In general during the storage period the moisture content varied from 73.57-77.51. The ANOVA table indicates that the F-ratio was significant for $0,5,15$ days of storage however it was no significant in case of 10 and 20 days of storage period.

\section{Hunter colour value of tofu}

The Hunter colour $\mathrm{L}$, $\mathrm{a}$ and $\mathrm{b}$ value of tofu are presented in table 5-7. The positive " $L$ " value indicate degree of lightness, the positive "a" value indicate the intensity of redness and the positive value of "b" indicates yellow colour (Schnell et al., 2005 and Shurong et al., 2006). The colour of tofu varies from light creamish with fine yellow. The gamma radiation treatment during storage exhibited yellowish colour product. The minimum Hunter $\mathrm{L}$, $\mathrm{a}$ and $\mathrm{b}$ colour value of tofu packed in BOPP (Table 5) were found to be at 0 days (64.38, 1.34 and 8.62), 5 days (69.7, 0.89 and 9.05), 10 days ( $63.79,1.33$ and 8.86), 15 days (73.81, 1.7 and 10.53) and 20 days 
(69.54, 1.17 and 10.11) respectively. The maximum Hunter $\mathrm{L}$, $\mathrm{a}$ and $\mathrm{b}$ colour value were found to be at 0 days $(76.63,2.24$, 12.42), 5 days $(76.28,2.15,12.04), 10$ days (77.41, 3.52, 13.46), 15 days(79.89, 1.77, 11.81) and 20 days $(79.77,3.7,13.01)$ respectively.

The Hunter L, a, b colour value of tofu packed in LDPE are presented in table 6. The table envisaged that minimum $\mathrm{L}, \mathrm{a}, \mathrm{b}$ value was observed to be at 0 days $(69.95,1.4$ and 10.64), 5days (70.7, 1.45 and 10.43), 10 days (73.24, 1.27 and 10.8), 15 days (75.25, 1.68 and 10.62), and 20 days (65.52, 1.15 and 9.64). However the maximum Hunter L, a, b colour value were found to be at 0 days (76.16, 2.52 and 12.2) 5 days (73.15, 6.63 and 13.6) 10 days (78.41, 2.11 and 13.11), 15 days (77.72, 2.21 and 12.29) and 20 days $(79.23,1.77$ and 12.01) of storage respectively.

The findings of Hunter L, a, b colour value of tofu packed in HDPE are given in table 7 that indicates the variability in tofu colour. The table envisaged that minimum $\mathrm{L}$, $\mathrm{a}$ and $\mathrm{b}$ value were observed to be at 0 days (64.86, 1.54 and 10.45), 5 days (69.45, 1.08 and 10.82), 10 days (73.88, 1.89 and 10.98), 15 days (71.89, 1.4 and 9.44) and 20 days (71.55, 1.47 and 10.45). However, the maximum Hunter L, a and b colour value were found to be at 0 days (75.22, 2.02 and 12.21), 5 days (76.69, 1.12 and 13.64), 10 days (77.21, 3.24 and 12.23), 15 days (77.12, 2.12 and 11.21) and 20 days $(79.79,2.34$ and 12.93) of storage respectively.

Table.1 Experimental plan and layout

\begin{tabular}{|c|c|c|c|c|c|c|c|}
\hline Packaging & Storage & \multicolumn{6}{|c|}{ Radiation doses (kGy) } \\
\hline \multirow{5}{*}{ BOPP } & 0 & Control & 0.25 & 0.50 & 0.75 & 1.0 & 1.25 \\
\hline & 5 & Control & 0.25 & 0.50 & 0.75 & 1.0 & 1.25 \\
\hline & 10 & Control & 0.25 & 0.50 & 0.75 & 1.0 & 1.25 \\
\hline & 15 & Control & 0.25 & 0.50 & 0.75 & 1.0 & 1.25 \\
\hline & 20 & Control & 0.25 & 0.50 & 0.75 & 1.0 & 1.25 \\
\hline \multirow[t]{5}{*}{ LDPE } & 0 & Control & 0.25 & 0.50 & 0.75 & 1.0 & 1.25 \\
\hline & 5 & Control & 0.25 & 0.50 & 0.75 & 1.0 & 1.25 \\
\hline & 10 & Control & 0.25 & 0.50 & 0.75 & 1.0 & 1.25 \\
\hline & 15 & Control & 0.25 & 0.50 & 0.75 & 1.0 & 1.25 \\
\hline & 20 & Control & 0.25 & 0.50 & 0.75 & 1.0 & 1.25 \\
\hline \multirow[t]{5}{*}{ HDPE } & 0 & Control & 0.25 & 0.50 & 0.75 & 1.0 & 1.25 \\
\hline & 5 & Control & 0.25 & 0.50 & 0.75 & 1.0 & 1.25 \\
\hline & 10 & Control & 0.25 & 0.50 & 0.75 & 1.0 & 1.25 \\
\hline & 15 & Control & 0.25 & 0.50 & 0.75 & 1.0 & 1.25 \\
\hline & 20 & Control & 0.25 & 0.50 & 0.75 & 1.0 & 1.25 \\
\hline
\end{tabular}


Table.2 Weight (g) of gamma radiated tofu at varying stored period

\begin{tabular}{|c|c|c|c|c|c|c|c|c|c|c|c|c|c|c|c|}
\hline \multirow{3}{*}{$\begin{array}{c}\text { Gamma } \\
\text { radiation } \\
\text { doses }\end{array}$} & \multirow{2}{*}{\multicolumn{5}{|c|}{$\begin{array}{c}\text { BOPP } \\
\text { Storage period }\end{array}$}} & \multirow{2}{*}{\multicolumn{5}{|c|}{$\begin{array}{c}\text { LDPE } \\
\text { Storage period }\end{array}$}} & \multirow{2}{*}{\multicolumn{5}{|c|}{$\begin{array}{c}\text { HDPE } \\
\text { Storage period }\end{array}$}} \\
\hline & & & & & & & & & & & & & & & \\
\hline & $\begin{array}{c}0 \\
\text { day }\end{array}$ & $\begin{array}{c}5 \\
\text { days }\end{array}$ & $\begin{array}{c}10 \\
\text { days }\end{array}$ & $\begin{array}{c}15 \\
\text { days }\end{array}$ & $\begin{array}{c}20 \\
\text { days }\end{array}$ & $\begin{array}{c}0 \\
\text { day }\end{array}$ & $\begin{array}{c}5 \\
\text { days }\end{array}$ & $\begin{array}{c}10 \\
\text { days }\end{array}$ & $\begin{array}{c}15 \\
\text { days }\end{array}$ & $\begin{array}{c}20 \\
\text { days }\end{array}$ & 0 day & $\begin{array}{c}5 \\
\text { days }\end{array}$ & $\begin{array}{c}10 \\
\text { days }\end{array}$ & $\begin{array}{c}15 \\
\text { days }\end{array}$ & $\begin{array}{c}20 \\
\text { days }\end{array}$ \\
\hline Control & 50 & 50 & 50 & 50 & 50 & 50 & 50 & 50 & 50 & 50 & 50 & 50 & 50 & 50 & 50 \\
\hline 0.25 kGy & 50.3 & 50.1 & 50.3 & 50.4 & 50.5 & 50.1 & 50.3 & 50.1 & 50.2 & 50.4 & 50.4 & 50.6 & 50.8 & 50.10 & 50.12 \\
\hline 0.5 kGy & 50.17 & 50.18 & 50.28 & 50.30 & 50.33 & 50.12 & 50.8 & 50.11 & 50.22 & 50.23 & 50.22 & 50.28 & 50.19 & 50.49 & 50.48 \\
\hline 0.75 kGy & 50.3 & 50.20 & 50.32 & 50.49 & 50.49 & 50.22 & 50 & 50.29 & 50.39 & 50.35 & 50.29 & 50.23 & 50.49 & 50.58 & 50.59 \\
\hline $1.00 \mathrm{kGy}$ & 50.6 & 50.37 & 50.46 & 50.57 & 50.68 & 50.37 & 50.25 & 50.35 & 50.52 & 50.51 & 50.36 & 50.45 & 50.50 & 50.65 & 50.72 \\
\hline $1.25 \mathrm{kGy}$ & 50.8 & 49.61 & 50.67 & 50.66 & 50.77 & 50.46 & 50.57 & 50.57 & 50.56 & 50.65 & 50.95 & 50.72 & 50.71 & 50.76 & 50.85 \\
\hline CD at $5 \%$ & NS & NS & NS & NS & NS & NS & NS & NS & NS & NS & NS & NS & NS & NS & NS \\
\hline SEm \pm & 0.13 & 0.078 & 0.11 & 0.13 & 0.42 & 0.13 & 0.09 & 0.13 & 0.08 & 0.42 & 0.11 & 0.1 & 0.13 & 0.07 & 0.43 \\
\hline
\end{tabular}

Table.3 Volume (ml) of gamma radiated tofu at varying stored period

\begin{tabular}{|c|c|c|c|c|c|c|c|c|c|c|c|c|c|c|c|}
\hline \multirow{3}{*}{$\begin{array}{c}\text { Gamma } \\
\text { radiation } \\
\text { doses }\end{array}$} & \multicolumn{5}{|c|}{ BOPP } & \multicolumn{5}{|c|}{ LDPE } & \multicolumn{5}{|c|}{ HDPE } \\
\hline & \multicolumn{5}{|c|}{ Storage period } & \multicolumn{5}{|c|}{ Storage period } & \multicolumn{5}{|c|}{ Storage period } \\
\hline & $\begin{array}{c}0 \\
\text { day }\end{array}$ & $\begin{array}{c}5 \\
\text { days }\end{array}$ & $\begin{array}{c}10 \\
\text { days }\end{array}$ & $\begin{array}{c}15 \\
\text { days }\end{array}$ & $\begin{array}{c}20 \\
\text { days }\end{array}$ & 0 day & $\begin{array}{c}5 \\
\text { days }\end{array}$ & $\begin{array}{c}10 \\
\text { days }\end{array}$ & $\begin{array}{c}15 \\
\text { days }\end{array}$ & $\begin{array}{c}20 \\
\text { days }\end{array}$ & 0 day & $\begin{array}{c}5 \\
\text { days }\end{array}$ & $\begin{array}{c}10 \\
\text { days }\end{array}$ & $\begin{array}{c}15 \\
\text { days }\end{array}$ & $\begin{array}{c}20 \\
\text { days }\end{array}$ \\
\hline 0.25 kGy & 50.2 & 50.4 & 50.3 & 50.6 & 50.6 & 50.1 & 50.2 & 50.4 & 50.4 & 50.5 & 50.2 & 50.4 & 50.3 & 50.3 & 50.6 \\
\hline 0.5 kGy & 50.3 & 50.7 & 50.4 & 50.5 & 50.5 & 50.2 & 50.3 & 50.4 & 50.5 & 50.5 & 50.3 & 50.5 & 50.4 & 50.6 & 50.6 \\
\hline 0.75 kGy & 50.3 & 50.6 & 50.6 & 50.6 & 50.7 & 50.3 & 50.2 & 50.5 & 50.5 & 50.5 & 50.3 & 50.6 & 50.6 & 50.5 & 50.5 \\
\hline $1.25 \mathrm{kGy}$ & 50.7 & 50.8 & 50.7 & 50.8 & 50.9 & 50.5 & 50.5 & 50.6 & 50.6 & 50.6 & 50.7 & 50.8 & 50.7 & 50.7 & 50.7 \\
\hline CD at $5 \%$ & 0.65 & 0.49 & 0.56 & 0.63 & NS & 0.65 & 0.54 & 0.65 & 0.52 & NS & 0.6 & 0.53 & NS & 0.48 & NS \\
\hline SEm \pm & 0.13 & 0.078 & 0.11 & 0.13 & 0.42 & 0.13 & 0.09 & 0.13 & 0.08 & 0.42 & 0.11 & 0.1 & 0.13 & 0.07 & 0.43 \\
\hline
\end{tabular}


Table.4 Moisture (\%) content in gamma radiated tofu packed in BOPP, LDPE and HDPE at varying storage period

\begin{tabular}{|c|c|c|c|c|c|c|c|c|c|c|c|c|c|c|c|}
\hline \multirow{3}{*}{$\begin{array}{c}\text { Gamma } \\
\text { radiation } \\
\text { doses }\end{array}$} & \multirow{2}{*}{\multicolumn{5}{|c|}{$\begin{array}{c}\text { BOPP } \\
\text { Storage period }\end{array}$}} & \multirow{2}{*}{\multicolumn{5}{|c|}{$\begin{array}{c}\text { LDPE } \\
\text { Storage period }\end{array}$}} & \multirow{2}{*}{\multicolumn{5}{|c|}{$\begin{array}{c}\text { HDPE } \\
\text { Storage period }\end{array}$}} \\
\hline & & & & & & & & & & & & & & & \\
\hline & $\begin{array}{c}0 \\
\text { day }\end{array}$ & 5 days & $\begin{array}{c}10 \\
\text { days }\end{array}$ & $\begin{array}{c}15 \\
\text { days }\end{array}$ & $\begin{array}{c}20 \\
\text { days }\end{array}$ & $\begin{array}{c}0 \\
\text { day }\end{array}$ & $\begin{array}{c}5 \\
\text { days }\end{array}$ & $\begin{array}{c}10 \\
\text { days }\end{array}$ & $\begin{array}{c}15 \\
\text { days }\end{array}$ & $\begin{array}{c}20 \\
\text { days }\end{array}$ & 0 day & $\begin{array}{c}5 \\
\text { days }\end{array}$ & $\begin{array}{c}10 \\
\text { days }\end{array}$ & $\begin{array}{c}15 \\
\text { days }\end{array}$ & $\begin{array}{c}20 \\
\text { days }\end{array}$ \\
\hline Control & 74.3 & 74.2 & 74.33 & 74.47 & 76.21 & 74.3 & 74.32 & 74.3 & 74.3 & 75.65 & 74.28 & 74.37 & 74.55 & 74.39 & 76.33 \\
\hline $0.25 \mathrm{kGy}$ & 74.6 & 74.7 & 74.64 & 74.78 & 76.32 & 74.5 & 74.61 & 74.6 & 74.67 & 76.24 & 74.57 & 74.62 & 74.65 & 74.81 & 77.1 \\
\hline 0.5 kGy & 74.17 & 74.2 & 74.25 & 74.42 & 75.96 & 74.21 & 74.11 & 74.17 & 74.29 & 75.31 & 74.23 & 74.25 & 74.82 & 74.51 & 75.56 \\
\hline 0.75 kGy & 74.3 & 74.32 & 74.32 & 74.51 & 76.41 & 74.24 & 74.23 & 74.3 & 74.4 & 74.39 & 74.27 & 74.36 & 74.38 & 74.62 & 76.51 \\
\hline 1.00 kGy & 73.6 & 73.58 & 73.66 & 73.78 & 76.56 & 73.52 & 73.52 & 73.6 & 73.68 & 75.71 & 73.57 & 73.64 & 75.01 & 73.72 & 76.89 \\
\hline $1.25 \mathrm{kGy}$ & 74.17 & 74.18 & 74.26 & 74.47 & 76.87 & 74.19 & 74.18 & 74.17 & 74.29 & 74.28 & 74.23 & 74.23 & 74.25 & 74.39 & 77.51 \\
\hline CD at $5 \%$ & 0.65 & 0.49 & 0.56 & 0.63 & NS & 0.65 & 0.54 & 0.65 & 0.52 & NS & 0.6 & 0.53 & NS & 0.48 & NS \\
\hline SEm \pm & 0.13 & 0.078 & 0.11 & 0.13 & 0.42 & 0.13 & 0.09 & 0.13 & 0.08 & 0.42 & 0.11 & 0.1 & 0.13 & 0.07 & 0.43 \\
\hline
\end{tabular}

Table.5 Hunter colour L, a, b value of gamma radiated tofu packed in BOPP at varying storage period

\begin{tabular}{|c|c|c|c|c|c|c|c|c|c|c|c|c|c|c|c|}
\hline \multirow{2}{*}{$\begin{array}{c}\text { Gamma } \\
\text { radiation doses }\end{array}$} & \multicolumn{3}{|c|}{0 day } & \multicolumn{3}{|c|}{5 days } & \multicolumn{3}{|c|}{10 days } & \multicolumn{3}{|c|}{15 days } & \multicolumn{3}{|c|}{20 days } \\
\hline & $\mathbf{L}$ & $\mathbf{a}$ & $\mathbf{b}$ & $\mathbf{L}$ & $\mathbf{a}$ & $\mathbf{b}$ & $\mathbf{L}$ & $\mathbf{a}$ & b & $\mathbf{L}$ & $\mathbf{a}$ & b & $\mathbf{L}$ & $\mathbf{a}$ & $\mathbf{b}$ \\
\hline Control & 69.76 & 2.32 & 12.42 & 71.66 & 0.89 & 10.18 & 72.72 & 2.17 & 13.46 & 74.55 & & 11.64 & 70.61 & 1.47 & 10.91 \\
\hline 0.25 kGy & 64.38 & 117 & 9.26 & 76.28 & 157 & 11.37 & 70.51 & 160 & 10.62 & 77.85 & 1.67 & 11.64 & 75.77 & 1.17 & 10.11 \\
\hline 0.50 kGy & 74.96 & 1.69 & 10.15 & 72.19 & 1.72 & 12.04 & 63.79 & 1.33 & 8.86 & 73.81 & 1.7 & 10.53 & 74.99 & 1.52 & 12.93 \\
\hline & & & & 69.7 & & & & & & & & & & 1.96 & 11 \\
\hline & 73.46 & 1.34 & 8.62 & 75.25 & & 12 & 71.71 & 1.95 & 10.39 & 78.36 & 1.71 & & 69.54 & 3.7 & 13.01 \\
\hline 1.25 kGy & 76.63 & 2.24 & 10.23 & 72.66 & 2.15 & 9.05 & 72.09 & 3.52 & 10.96 & 79.89 & 1.7 & 11.16 & 79.77 & 2.22 & 11.45 \\
\hline
\end{tabular}


Table.6 Hunter colour L, a, b value of gamma radiated tofu packed in LDPE at varying storage period

\begin{tabular}{|c|c|c|c|c|c|c|c|c|c|c|c|c|c|c|c|}
\hline \multirow{2}{*}{$\begin{array}{l}\text { Gamma } \\
\text { radiation } \\
\text { doses }\end{array}$} & \multicolumn{3}{|c|}{0 day } & \multicolumn{3}{|c|}{5 days } & \multicolumn{3}{|c|}{10 days } & \multicolumn{3}{|c|}{15 days } & \multicolumn{3}{|c|}{20 days } \\
\hline & $\mathbf{L}$ & $\mathbf{a}$ & b & $\mathbf{L}$ & $\mathbf{a}$ & b & $\mathbf{L}$ & $\mathbf{a}$ & b & $\mathbf{L}$ & $\mathbf{a}$ & $\mathbf{b}$ & $\mathbf{L}$ & $\mathbf{a}$ & b \\
\hline Control & 72.16 & 1.95 & 10.64 & 72.77 & 6.63 & 12.72 & 73.24 & 1.27 & 10.8 & 77.72 & 2.21 & 12.29 & 76.57 & 1.64 & 11.69 \\
\hline $0.25 \mathrm{kGy}$ & 74.6 & 1.81 & 11.12 & 73.15 & 1.45 & 10.47 & 70.61 & 2.11 & 13.11 & 77.6 & 1.82 & 11.48 & 74.51 & 1.31 & 10.79 \\
\hline 0.50 kGy & 76.16 & 1.6 & 11.26 & 65.77 & 8.89 & 13.24 & 78.41 & 1.69 & 11.9 & 74.88 & 2.04 & 10.95 & 65.52 & 1.15 & 9.64 \\
\hline 0.75 kGy & 72.47 & 2.52 & 11.06 & 72.14 & 1.96 & 11.05 & 78.41 & 1.42 & 11.14 & 76.25 & 1.88 & 10.62 & 79.23 & 1.31 & 10.24 \\
\hline $1.00 \mathrm{kGy}$ & 69.95 & 1.86 & 10.92 & 70.7 & 2.45 & 13.6 & 77.98 & 1.5 & 11.02 & 75.37 & 1.89 & 11.37 & 72.38 & 1.24 & 12.01 \\
\hline $1.25 \mathrm{kGy}$ & 70.92 & 1.4 & 12.2 & 70.73 & 1.68 & 10.43 & 78.04 & 1.55 & 11.31 & 75.25 & 1.68 & 10.93 & 74.3 & 1.77 & 11.25 \\
\hline
\end{tabular}

Table.7 Hunter colour L, a, b value of gamma radiated tofu packed in HDPE at varying storage period

\begin{tabular}{|c|c|c|c|c|c|c|c|c|c|c|c|c|c|c|c|}
\hline \multirow{2}{*}{$\begin{array}{l}\text { Gamma } \\
\text { radiation } \\
\text { doses }\end{array}$} & \multicolumn{3}{|c|}{0 day } & \multicolumn{3}{|c|}{5 days } & \multicolumn{3}{|c|}{10 days } & \multicolumn{3}{|c|}{15 days } & \multicolumn{3}{|c|}{20 days } \\
\hline & $\mathbf{L}$ & $\mathbf{a}$ & $\mathbf{b}$ & $\mathbf{L}$ & $\mathbf{a}$ & $\mathbf{b}$ & $\mathbf{L}$ & $\mathbf{a}$ & $\mathbf{b}$ & $\mathbf{L}$ & $\mathbf{a}$ & b & $\mathbf{L}$ & $\mathbf{a}$ & $\mathbf{b}$ \\
\hline Control & 70.6 & 1.55 & 10.45 & 72.2 & 1.26 & 12.51 & 76.71 & 3.24 & 12.23 & 77.12 & 1.47 & 10.62 & 71.55 & 1.96 & 12.93 \\
\hline 0.25 kGy & 72.43 & 1.88 & 11.05 & 76.23 & 1.08 & 12.72 & 77.21 & 2.89 & 11.58 & 72.87 & 1.4 & 10.98 & 76.92 & 1.56 & 11 \\
\hline 0.50 kGy & 69.12 & 1.54 & 12.21 & 69.45 & 2.12 & 13.64 & 73.88 & 2.47 & 10.98 & 76.25 & 1.66 & 9.44 & 71.85 & 1.47 & 10.52 \\
\hline 0.75 kGy & 73.49 & 1.62 & 10.6 & 75.63 & 1.54 & 11.22 & 76.22 & 1.89 & 11.06 & 73.08 & 2.12 & 11.21 & 72.06 & 2.34 & 11.45 \\
\hline 1.00 kGy & 75.22 & 2.02 & 11.74 & 72.85 & 1.75 & 11.35 & 75.35 & 2.75 & 10.99 & 74.32 & 1.75 & 10.85 & 77.05 & 2.21 & 10.91 \\
\hline $1.25 \mathrm{kGy}$ & 64.86 & 1.78 & 10.72 & 76.69 & 1.49 & 10.82 & 75.41 & 2.32 & 11.54 & 71.89 & 1.93 & 10.65 & 79.79 & 1.69 & 10.45 \\
\hline
\end{tabular}


In this context there was no significant difference among the treatment combination for weight and volume of tofu. The findings indicate that gamma radiation doses could not contribute any significant effect on increase or decrease in weight and volume of tofu during storage.

The effect of radiation on tofu packed in BOPP, LDPE and HDPE showed no significant contribution of treatment during storage period for moisture (20 days) respectively, however for remaining period $(0,5,15$ days $)$ the effect on the content of above constituents was significant. The findings of Pablo et al., (1971), Ahmad et al., (1972), Cuevas-Ruiz et al., (1972), Nagvi and Moy (1985), Thomas and Janave (1975), Durbey et al., (1984) and Olsan et al., (1989) given critical direction that biochemical constituents of tofu has significant difference due to radiation treatment. The effect of radiation may be due to removal of water. The protein, carbohydrate, and fat biomolecules may also undergo for conformational changes due to radiation which may cause the variation in the concentration during storage.

The colour of products is very important attribute that determines the acceptability of product in the market. In view of this colour of treated and packed tofu has been evaluated by hunter colour lab. The Hunter colour L, a, $b$, value of tofu shows that the colour of tofu varies from light creamy with fine yellow colour. The gamma radiation treatment during storage exhibited yellowish colour product. To substantiate the present findings as such no reports are available in the literature, however Saxena and Singh (1997), Nasim et al., (1985), Grover et al., (1989) and Chauhan et. al., (1998) have also reported the similar colour in fresh and stored tofu. However, Mami et al., 2012 and Kortei et al., 2015 recorded higher values of $\mathrm{L}$, $\mathrm{a}$ and $\mathrm{b}$ for effect of gamma radiation on color of Agaricus bisporus during storage which also in support with our research. Colour of tofu is known to be affected by physico-chemical properties and pretreatments (Matser et al., 2000, Kotwaliwale et al., 2010 and Aktas et al., 2011).

Intensified health problems of the society resulted in a change of human attitude to the quality of consumed products. Within the last few years the interest in "safe food" has increased significantly. The Hunter colour L, $a, b$, value of tofu shows that the colour of tofu varies from light creamy with fine yellow colour. The gamma radiation treatment during storage exhibited yellowish colour product. As earlier researchers stated that colour of product changed after irradiation. In this finding seems to be that effect of radiation may be due to removal of water. The protein, carbohydrate, and fat biomolecules may also undergo for conformational changes due to radiation which may cause the variation in the concentration during storage.

In conclusion, although the presented results show that colour loss due to irradiation was significant, to the application of low-dose gamma radiation by the local food industry would improve the hygienic quality and extend shelf-life of tofu enhance their competitiveness in domestic and export markets.

\section{References}

Ahmad, M., Naqvi, M.H., Hussain, A. and Hussain, A.M. (1972). Effect of gamma radiation and packaging on the post harvest life of guava (Psidium guajava L.), Philippine Journal of Science. 101 (1-2):71-80.

Aktas, T., Sahin, F.H., Orak, H. and Ulger, P. (2011). Influence of pretreatments and drying methods on color parameters and lycopene content of dried tomato. Bulgarian Journal of Agricultural 
Sciences, 17(6): 867-881.

Anon, (1998). Karnataka. Statistics Department of Horticulture. Government of Karnataka. Pp 1-2.

AOAC, (1984). Officials methods of Analysis. Association of official Analytical chemists. Washington. D.C., USA.

Campbell, B.L., Nelson, R.G., Ebel, C.E., Dozier, W.A., Adrian, J.L. and Hockema, B.R. (2004). Fruit quality characteristics that affect consumer preferences for satsuma mandarins. Hort. Science, 39 (7) 1664-1666.

Chauhan, G.S., Singh, J.D. and Tomar, N.S. (1998). Nutritional changes in soymilk subjected to different physical and chemical treatments. J. Food Sci. \& Technol. 35 (3) 271-273.

Cuevas-Ruiz, J., Garham, H.D., and Luse, R.A. (1972). Gamma radiation effects on biochemical components of Puerto Rican mangoes. J. Agri. The university of Puerto-Rico, 56(1):2632.

Dahlquist, E., (2013). Biomass as Energy Source: Resources, Systems and Applications. CRC Press; 300(10).

Durbey, I.A., Rensburg, L.J. and Schabort, J.C. (1984). Malic enzyme activity and related biochemical aspects during ripening of gamma irradiated mango fruit. Phytochemistry. 23(7): 13831386.

FAO/WHO, (1976). Guidelines for Developing an effective national food control system. Rome : FAO.

Grover, M. and Yagi, S.M. (1989). Studies on soy paneer, J. Food. Sci. Technol. 26(4) 194-197.

Kortei, N.K., Odamtten, G.T., Obodai, M., Appiah, V., Akonor. P.T. (2015). Determination of color parameters of gamma irradiated fresh and dried mushrooms during storage. Croatian Journal of Food Technology,
Biotechnology and Nutrition. 10 (1-2). Pp. 66-71.

Kotwaliwale, N., Bakane, P. and Verma, A. (2007). Changes in textural and optical properties of oyster mushroom during hot air drying. Journal of Food Engineering, 78(4): 1207-1211.

Mami, Y., Peyvast, G., Ziaie, F., Ghasemnezhad, M. and Salmanpour, V. (2013). Improvement of shelf-life and postharvest quality of white button mushroom by $60 \mathrm{CO} \gamma$-ray irradiation. Plant Knowledge Journal, 2(1): 1-7.

Matser, A.M., Knott, E.R., Teunissen, P.G.M. and Bartels, P.V. (2000). Effects of high isostatic pressure on mushrooms. Journal of Food Engineering, 45: 1116.

Maurya, S.B., Shukla, S.S. and Gour, L. (2018). Nutritional quality of tofu (Soy paneer) as affecting by gamma irradiation during storage. International Journal of Chemical Studies; 6(1): 879-883

Mexis, S.F., Badeka, A.V., Chouliara, E., Riganakos, K. and Kontominas M.G. (2009). Effect of g- irradiation on the physicochemical and sensory properties of raw unpeeled almond kernels (Prunus dulcis). Innovat Food Sci Emerg Tech. (10) 87-92.

Nagvi, N.Y., and Moy, J.H. (1985). Quality of gamma irradiated California Valencia oranges. J. Food. Sci., 50(1):215-218.

Nasim, M., Mital, B.K. and Tyagi, S.M. (1985). Development of a process for preparation of soy paneer, J. Food. Sci. Technol. 23, 69-72.

Olson, K.L., Hungate, F.P., Darke, S.R. and Eakin, D.E. (1989). Red Delicious apple response to low dose radiation. J. Food Quality. 12:107-113.s .

Pablo, I.S., Manalo, J.A. and Cardeno, V.A. (1971). Sensory, chemical, nutritional evaluation on the effect of ionizing 
radiation on mangoes (Mangifera indica, Linn). Disinfestations of fruit by irradiation.

Saxena, S. and Singh, G. (1997). Suitability of new soybean cultivars in the production of soy milk. J. Food Sci. Technol, 34(2):150-152.

Schnell, R.J, Silva, A.D., Meerow, A.W., Winterstein, M., Cervantes, C. and Brown, J.S. (2005). Determination of color and fruit traits of half-sib families of mango (Magnifera indica L.). Proc. Fla. State Hort. Soc., 118 253-257.
Shurong, L., Meixu, G., Chuanyao, W. (2006). Use of irradiation to ensure hygienic quality of fresh pre-cut and Blanched vegetables and tofu. Proceedings. The Joint FAO/IAEA Programme of Nuclear Techniques in Food and Agriculture, Islamabad, Pakistan, July 22-30.

Thomas, P., and Janave, M.T. (1975). Effects of gamma irradiation and storage temperature on arytenoids and ascorbic acid content of mangoes on ripening. J. Sci. of Food and Agri.; 26(10):1503-1512.

\section{How to cite this article:}

Maurya, S.B., S.S. Shukla and Lokesh Gour. 2018. Studies on Physical and Hunter Colour of Gamma Irradiated Tofu (Soy paneer). Int.J.Curr.Microbiol.App.Sci. 7(03): 2008-2018. doi: https://doi.org/10.20546/ijcmas.2018.703.236 